\title{
Management of Chronic Hepatitis B: An Overview of Practice Guidelines for Primary Care Providers
}

\author{
Steven-Huy Han, MD, and Tram T. Tran, MD
}

Despite the introduction of hepatitis B virus (HBV) vaccination programs, chronic hepatitis B (CHB) remains an important disease burden worldwide and in the United States. A number of clinical practice guidelines are available to assist in the clinical management of CHB by providing recommendations regarding screening and diagnosis, treatment indications, and the choice, duration, and monitoring of treatment. Adherence to these guidelines has proven beneficial in terms of better treatment compliance, improved clinical outcomes, and lower likelihoods of emergency admission. This review summarizes current recommendations from the major clinical CHB practice guidelines and presents a simple algorithm for the treatment of patients with CHB to help primary care providers make informed choices in clinical practice. In general, antiviral treatment should be initiated in patients with CHB who have a high risk of liver-related morbidity and who are likely to respond to treatment, that is, patients with persistently elevated serum HBV DNA and either increased serum alanine aminotransferase concentrations or advanced liver disease. In patients who are eligible for antiviral therapy, treatment should be initiated with one of the recommended firstline therapies (pegylated interferon- $\alpha$, entecavir, or tenofovir), and treatment efficacy should be monitored regularly for serum HBV DNA, alanine aminotransferase, and serologic responses. Patients who are not immediately considered for treatment should be monitored and started on antiviral therapy in case of disease progression. A number of issues in CHB management remain controversial or unresolved, such as identifying treatment candidates, managing partial or nonresponders, and predicting treatment response; we discuss some of the latest evidence around these topics. (J Am Board Fam Med 2015;28:822-837.)

Keywords: Health Care Providers; Hepatitis B, Chronic; Practice Guideline; Primary Health Care

Despite vaccination programs, chronic hepatitis B (CHB) remains an important disease burden worldwide and in the United States. Globally, 240 million people are infected with the hepatitis B virus

This article was externally peer reviewed.

Submitted 2 December 2014; revised 2 April 2015; accepted 6 April 2015.

From the UCLA Medical Center, Pfleger Liver Institute, Los Angeles, CA (S-HH); and the Liver Disease and Transplant Center, Cedars-Sinai Medical Center, Los Angeles, CA (TTT).

Funding: Editorial assistance was provided by Isabelle Kaufmann of ArticulateScience UK, which was supported by a grant from Bristol-Myers Squibb.

Conflict of interest: $\mathrm{S}-\mathrm{HH}$ has received research grants for clinical studies from Bristol-Myers Squibb and Gilead Sciences. TTT has received research grants and personal fees from Bristol-Myers Squibb and Gilead Sciences, and personal fees from Novartis.

Disclaimer: The sponsor had no role in the development of the content of the manuscript. Bristol-Myers Squibb reviewed the final article for scientific accuracy only. The
$(\mathrm{HBV}),{ }^{1}$ and 650,000 people die every year from HBV-related cirrhosis or hepatocellular carcinoma (HCC). ${ }^{2}$ In the United States, $4.6 \%$ of the population ( $\sim 11$ million people) have been exposed to $\mathrm{HBV}$, and $0.27 \%(\sim 700,000$ people $)$ are affected by $\mathrm{CHB}^{3}$

Treatment of $\mathrm{CHB}$ has been shown to reduce the risk of HBV-related liver complications, including decompensated cirrhosis and HCC. ${ }^{4-9}$ $\mathrm{CHB}$ practice guidelines, such as those published by the American Association for the Study of

content of the review, that is, the data selection, drafting and reviewing of the manuscript, and the decision on any of the conclusions, is entirely the product of the authors and represents their opinion.

Corresponding author: Steven-Huy Han, MD, UCLA Medical Center, Pfleger Liver Institute, 200 UCLA Medical Plaza, Suite 214, Los Angeles, CA 90095 (E-mail: steven.han@ucla.edu). 
Liver Diseases (AASLD), the Asian Pacific Association for the Study of the Liver (APASL), and the European Association for the Study of the Liver (EASL),${ }^{10-12}$ assist health care providers and patients in the management of $\mathrm{CHB}$ by providing evidence-based recommendations regarding screening, diagnosis (hepatitis B surface antigen [HBsAg] test), identification of treatment candidates, and the choice, duration, and monitoring of treatment. Adherence to practice guidelines is associated with better treatment compliance and lower likelihood of emergency admissions, thus improving clinical outcomes, with no increase in total health care costs. ${ }^{13}$

However, there is evidence suggesting that, among primary care providers, there is a lack of awareness and insufficient adherence to the current recommendations for CHB management. A number of US studies demonstrated poor compliance with CHB practice guidelines among treating physicians, in particular regarding regular monitoring of CHB status (using markers such as HBV DNA and alanine aminotransferase [ALT]), performance of liver biopsy to guide treatment decisions, treatment initiation among patients considered eligible for anti-HBV therapy, use of recommended agents, and HCC surveillance ${ }^{14-16}$; this was partially the result of a lack of familiarity with practice guidelines ${ }^{15}$ and was more common among primary care physicians than among specialists. ${ }^{17}$ Another study assessing perceptions of CHB among primary care physicians in the US Asian American community showed that despite awareness of the high prevalence of CHB among Asian Americans, $62 \%$ of the primary care physicians were unfamiliar with the current major CHB treatment guidelines. ${ }^{18}$ Likewise, among Spanish and Chinese physicians, only half made recommendations that were in line with current practice guidelines, such as indications for CHB therapy and treatment end points, or were familiar with the efficacy rates of antiviral agents. ${ }^{19,20}$

This review summarizes the current recommendations of the 3 major practice guidelines published by AASLD, APASL, and EASL, condensing them into a simple treatment algorithm for CHB. The data summarized here will help primary care providers make informed choices regarding the management of $\mathrm{CHB}$ in clinical practice. We also discuss issues that remain controversial or unresolved and directions for future research; evidence around these topics was gathered by searching PubMed using terms related to these topics.

\section{Markers of HBV Infection and CHB Disease Progression}

The progression of CHB depends on the interaction between the virus and the host's immune response, with the main morbidity burden resulting from long-term liver complications (cirrhosis and HCC) that can develop as a result of a persistent immune response against $\mathrm{HBV}$-infected hepatocytes. A number of surrogate markers that correlate with clinical outcomes are used in clinical practice to monitor and predict disease progression. ${ }^{21-23} \mathrm{HBsAg}$, the main marker of $\mathrm{HBV}$ infection, is detectable 1 to 2 weeks after exposure, and $\mathrm{HBsAg}$ clearance is considered a sign of viral clearance. Hepatitis B e antigen ( $\mathrm{HBeAg}$ ) reflects active viral replication and transcription, and indicates infectivity. Serum HBV DNA is another marker of ongoing viral replication: Higher HBV DNA levels reflect increased levels of circulating virus and, importantly, are associated with poorer outcomes. For example, several landmark long-term cohort studies showed that HBV DNA more than $\sim 2 \times 10^{4} \mathrm{IU} / \mathrm{mL}$ $\left(\sim 10^{5}\right.$ copies $\left./ \mathrm{mL}\right)$ is associated with a significantly greater risk of HCC and mortality than a lower viral load. ${ }^{24-26}$ Serum ALT is a marker of liver inflammation; ALT concentrations above the upper limit of normal (ULN) are indicative of injury to hepatocytes. The status of liver disease can also be directly assessed using liver biopsy or noninvasive techniques such as transient elastography (FibroScan); in addition, a number of other noninvasive tests that measure serum markers of liver damage (FibroSpect, FibroSure) have been developed recently. ${ }^{27,28}$

CHB typically progresses through 4 different phases (Table 1); however, the duration of the individual phases and the overall course of the disease depend strongly on the age at which the infection was acquired. In the earliest phase- the immunetolerant phase-no immune response is raised against the virus, and the probability of HBeAg loss and seroconversion is therefore low. This phase is characterized by high levels of HBV DNA and HBeAg positivity but normal ALT and near-normal liver histology. In the absence of liver inflammation, as signified by normal ALT concentrations, liver disease is unlikely to develop. If $\mathrm{HBV}$ has been acquired peri- 


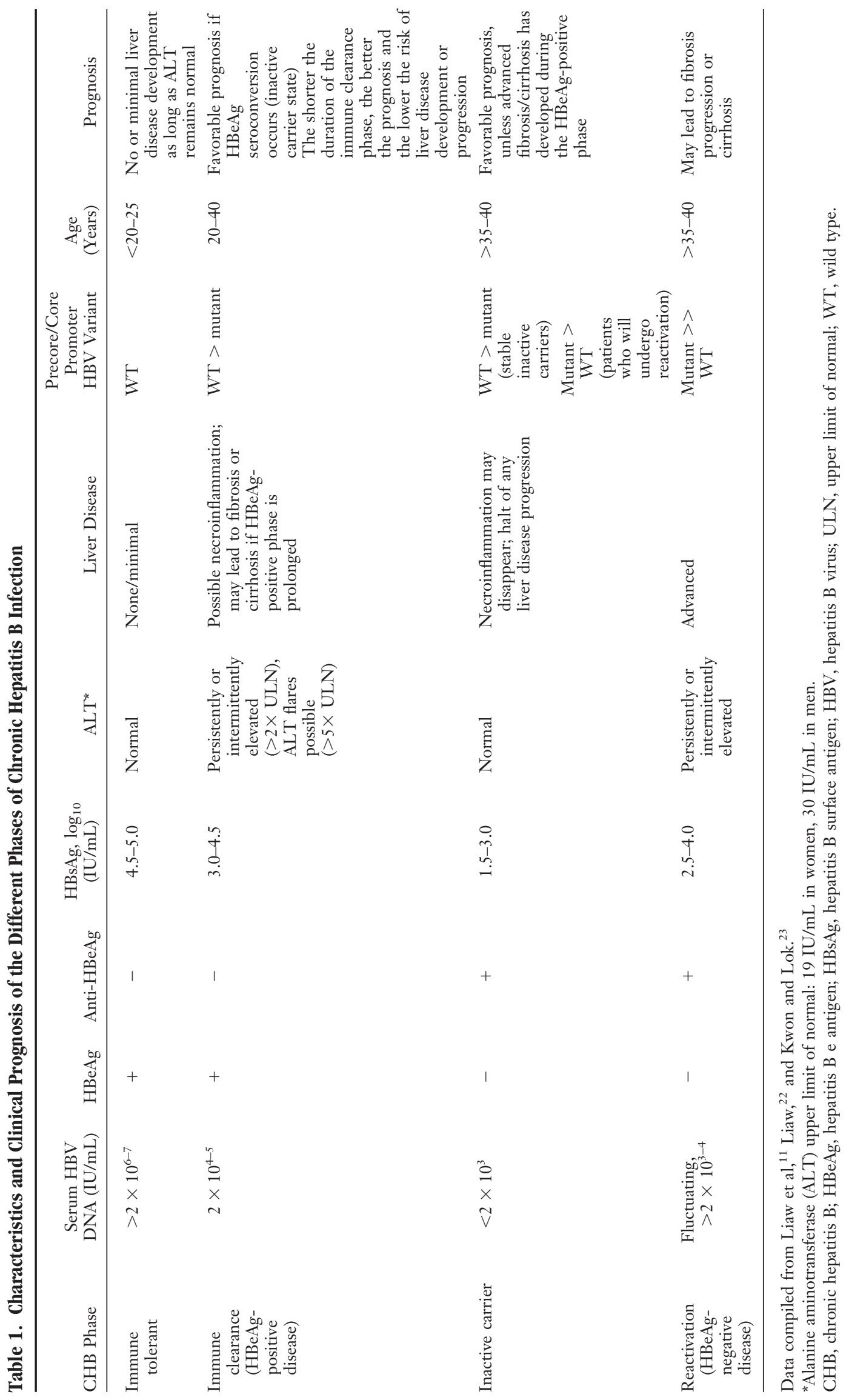


natally or during early childhood (which is usually the case in regions where HBV is endemic, such as Asia), the immune-tolerant phase is long, typically lasting 2 or 3 decades; by contrast, it may be absent or very short in adult-acquired HBV. Thus, patients in the immune-tolerant phase are generally children or young adults from regions where HBV is endemic.

If an immune response is mounted against the virus, the disease progresses to the immune clearance phase. In this phase, called $\mathrm{HBeAg}$-positive $\mathrm{CHB}$, the probability of achieving HBeAg seroclearance (ie, the loss of $\mathrm{HBeAg}$ and appearance of anti-HBeAb) is higher, with annual rates of spontaneous $\mathrm{HBeAg}$ seroclearance ranging from $2 \%$ to $20 \%$. As a result of viral clearance, $\mathrm{HBV}$ DNA levels decline, but because of the ongoing liver injury associated with the immune response, ALT concentrations are intermittently or persistently elevated and may episodically reach up to 5 times the ULN ("ALT flares").

Patients who achieve HBeAg seroconversion may enter the inactive carrier phase, characterized by $\mathrm{HBeAg}$ negativity, anti-HBeAb positivity, low or undetectable HBV DNA, and normal ALT. Unless advanced liver disease has developed during the preceding immune clearance phase, the inactive carrier phase confers a favorable prognosis, with improvements in liver histology and a halt of disease progression. ${ }^{29}$ HBeAg seroconversion may also be followed by HBsAg seroclearance, which is considered to be a state as close to remission as possible and is associated with a significant reduction (albeit not complete elimination) of HCC risk. ${ }^{30}$ If $\mathrm{HBeAg}$ seroconversion occurs late in life (after the age of $\sim 40$ years), however, the prolonged immune response may still allow liver disease to progress. ${ }^{31}$ Importantly, HBV reactivation may occur, either as a result of $\mathrm{HBeAg}$ seroreversion (ie, restored $\mathrm{HBeAg}$ positivity caused by reactivation of wildtype HBV), or, more frequently, as a result of the emergence of HBV mutants that no longer express HBeAg (ie, precore or basal core promoter $[\mathrm{PC} / \mathrm{BCP}]$ mutants); the latter event, which results in $\mathrm{HBeAg}$-negative $\mathrm{CHB}$, is particularly common among patients from Asia or the Mediterranean, where the prevalence of PC/BCP mutants is high. ${ }^{32} \mathrm{HBV}$ reactivation can occur after years or decades of the inactive carrier state and represents, especially in the case of HBeAg-negative
$\mathrm{CHB}$, a late stage of the infection generally associated with advanced liver disease. ${ }^{21-23}$ Annual relapse rates following $\mathrm{HBeAg}$ seroconversion are estimated to be $2 \%$ to $3 \%$ among Asians, with the highest rates in males, patients infected by genotype $\mathrm{C}$, and those achieving $\mathrm{HBeAg}$ seroconversion after the age of 40 years. ${ }^{22}$

\section{HBV Screening}

$\mathrm{CHB}$ in the immune-tolerant or inactive carrier phase is often asymptomatic; therefore, a considerable proportion of patients do not know they are infected, thereby increasing the risk of developing severe liver complications and spreading the virus to others. Among people affected by CHB, an estimated $65 \%$ in the United States and up to $90 \%$ in the European Union are not aware of their infection. ${ }^{33,34}$ In Western countries, people originating from a high or intermediate endemic area (Asia, Africa, Australia, Central and South America, and the Mediterranean) account for $50 \%$ to $95 \%$ of all patients with $\mathrm{CHB}^{35}$; thus, although in the United States the overall prevalence of $\mathrm{HBV}$ is $<1 \%$, it is $10 \%$ or even higher among Asian Americans. ${ }^{35,36} \mathrm{HBV}$ screening allows early diagnosis and treatment of infected individuals, as well as vaccination of their close contacts, to reduce vertical and horizontal transmission. ${ }^{36} \mathrm{CHB}$ practice guidelines, and the recently published guidelines from the US Preventive Services Task Force, recommend HBV screening among high-risk populations, which include (1) people born in high or intermediate endemic areas (for a complete list see ref. ${ }^{37}$ ), (2) people who were not vaccinated as infants and whose parents were born in regions with high $\mathrm{HBV}$ endemicity (Southeast Asia, China, sub-Saharan Africa), (3) people needing chemotherapy or immunosuppressive therapy, (4) people with multiple sexual partners or a history of sexually transmitted disease, (5) people who have ever used injecting drugs, (6) individuals infected with human immunodeficiency virus or hepatitis $C$ virus, and (7) household contacts or sexual partners of HBV-infected people. ${ }^{10,35}$ Testing should include a serologic assay for HBsAg, with chronic $\mathrm{HBV}$ infection confirmed by the persistence of HBsAg for at least 6 months. ${ }^{35}$ 


\section{Overview Management of CHB}

The primary goal of antiviral treatment is to prevent the development and progression of HBVrelated liver disease. However, not all patients need to be treated. In general, patients considered to be treatment candidates are those in the immune clearance phase (HBeAg-positive $\mathrm{CHB}$ ), in whom treatment aims to stimulate $\mathrm{HBeAg}$ seroconversion and minimize liver injury, and patients with a high risk of liver-related morbidity, that is, those with $\mathrm{HBeAg}$-negative $\mathrm{CHB}$ and/or advanced liver disease, in whom treatment aims to prevent further progression or reverse existing liver disease..$^{10-12}$ In these patients, antiviral therapy has been shown to suppress HBV replication, normalize ALT concentrations, increase $\mathrm{HBeAg}$ seroconversion (in $\mathrm{HBeAg}$-positive patients), reverse fibrosis and cirrhosis, and improve liver function in decompensated liver disease. ${ }^{10-12,38-40}$ Antiviral therapy with nucleo(s)tide analogs (NUCs) has also recently been shown to reduce the risk of $\mathrm{HBV}$-related HCC and mortality. ${ }^{4-9}$
Patients with persistently normal or minimally elevated ALT (eg, patients in the immune-tolerant phase) have a low risk of liver injury and tend to have a poorer response to antiviral therapy ${ }^{41,42}$; therefore, treatment is generally not indicated unless there is evidence of advanced liver disease. ${ }^{10-12}$ Likewise, inactive carriers do not require treatment since this phase is associated with a favorable outcome. ${ }^{10-12}$ For both groups of patients, however, regular monitoring of HBV DNA and ALT is recommended to detect any changes in disease status that might require treatment initiation. ${ }^{10-12}$

A detailed summary of the criteria for $\mathrm{CHB}$ treatment initiation, as recommended by the current AASLD, APASL, and EASL practice guidelines, is shown in Table 2. In general, the societal recommendations are similar; however, there are minor differences with regard to the specific cut offs for HBV DNA and ALT at which antiviral therapy should be initiated. Figure 1 shows a simple treatment algorithm for HBeAg-positive, HBeAgnegative, and cirrhotic $\mathrm{CHB}$, combining the rec-

Table 2. Summary of Anti-Hepatitis B Virus Treatment Indications as Recommended by Major Practice Guidelines

\begin{tabular}{|c|c|c|c|}
\hline & \multicolumn{3}{|c|}{ Practice Guidelines } \\
\hline & $\mathrm{AASLD}^{10}$ & APASL $^{11}$ & $\mathrm{EASL}^{12}$ \\
\hline \multirow[t]{3}{*}{ HBeAg-positive } & $\begin{array}{l}\text { - } \mathrm{HBV} \text { DNA }>20,000 \mathrm{IU} / \mathrm{mL} \\
\text { - } \mathrm{ALT}>2 \times \mathrm{ULN} \\
\text { - No spontaneous HBeAg } \\
\text { seroconversion after } \\
\text { 3-6 months' observation }\end{array}$ & $\begin{array}{l}\text { - } \mathrm{HBV} \text { DNA } \geq 20,000 \mathrm{IU} / \mathrm{mL} \\
\text { - } \mathrm{ALT} \geq 2 \times \mathrm{ULN}\end{array}$ & $\begin{array}{l}\text { - } \mathrm{HBV} \text { DNA }>20,000 \mathrm{IU} / \mathrm{mL} \\
\text { - } \mathrm{ALT}>2 \times \mathrm{ULN}\end{array}$ \\
\hline & $\begin{array}{l}\text { - } \mathrm{HBV} \text { DNA }>20,000 \mathrm{IU} / \mathrm{mL} \\
\text { - } \mathrm{ALT} \leq 2 \times \mathrm{ULN} \\
\text { - } \text { Moderate or worse liver } \\
\text { inflammation or significant } \\
\text { fibrosis (on biopsy*) }\end{array}$ & $\begin{array}{l}\text { - } \mathrm{HBV} \text { DNA } \geq 20,000 \mathrm{IU} / \mathrm{mL} \\
\text { - } \mathrm{ALT} \geq 1 \text { to }<2 \times \mathrm{ULN} \\
\text { - Moderate or worse liver } \\
\text { inflammation or fibrosis } \\
\text { (on biopsy or noninvasive } \\
\text { fibrosis assessment*) }\end{array}$ & $\begin{array}{l}\text { - } \mathrm{HBV} \text { DNA > } 2000 \mathrm{IU} / \mathrm{mL} \\
\text { - } \mathrm{ALT}>1 \times \mathrm{ULN} \\
\text { - Moderate or worse liver } \\
\text { inflammation or moderate } \\
\text { fibrosis (using a standardized } \\
\text { scoring system }{ }^{\dagger} \text { ) }\end{array}$ \\
\hline & $\begin{array}{l}\text { - HBV DNA >2000 IU/mL } \\
\text { - Cirrhosis }\end{array}$ & $\begin{array}{l}\text { - } \mathrm{HBV} \text { DNA } \geq 2000 \mathrm{IU} / \mathrm{mL} \\
\text { - Advanced fibrosis/cirrhosis }\end{array}$ & $\begin{array}{l}\text { - Detectable HBV DNA } \\
\text { - Cirrhosis }\end{array}$ \\
\hline \multirow[t]{3}{*}{ HBeAg-negative } & $\begin{array}{l}\text { - } \mathrm{HBV} \text { DNA >20,000 IU/mL } \\
\text { - } \mathrm{ALT}>2 \times \mathrm{ULN}\end{array}$ & $\begin{array}{l}\text { - } \mathrm{HBV} \text { DNA } \geq 2000 \mathrm{IU} / \mathrm{mL} \\
\text { - } \mathrm{ALT}>2 \times \mathrm{ULN}\end{array}$ & $\begin{array}{l}\text { - } \mathrm{HBV} \text { DNA >20,000 IU/mL } \\
\text { - } \mathrm{ALT}>2 \times \mathrm{ULN}\end{array}$ \\
\hline & $\begin{array}{l}\text { - } \mathrm{HBV} \text { DNA }>2000 \mathrm{IU} / \mathrm{mL} \\
\text { - } \mathrm{ALT} \geq 1-2 \times \text { ULN } \\
\text { - Moderate or worse liver } \\
\text { inflammation or significant } \\
\text { fibrosis (on biopsy) }\end{array}$ & $\begin{array}{l}\text { - } \mathrm{HBV} \text { DNA } \geq 2000 \mathrm{IU} / \mathrm{mL} \\
\text { - } \mathrm{ALT} \geq 1 \text { to }<2 \times \mathrm{ULN} \\
\text { - Moderate or worse liver } \\
\text { inflammation or fibrosis } \\
\text { (on biopsy or noninvasive } \\
\text { fibrosis assessment }{ }^{*} \text { ) }\end{array}$ & $\begin{array}{l}\text { - } \mathrm{HBV} \text { DNA > } 2000 \mathrm{IU} / \mathrm{mL} \\
\text { - } \mathrm{ALT}>1 \times \mathrm{ULN} \\
\text { Moderate or worse liver } \\
\text { inflammation or moderate } \\
\text { fibrosis }\end{array}$ \\
\hline & $\begin{array}{l}\text { - } \mathrm{HBV} \text { DNA >2000 IU/mL } \\
\text { - Cirrhosis }\end{array}$ & $\begin{array}{l}\text { - } \mathrm{HBV} \text { DNA } \geq 2000 \mathrm{IU} / \mathrm{mL} \\
\text { - Advanced fibrosis/cirrhosis }\end{array}$ & $\begin{array}{l}\text { - Detectable HBV DNA } \\
\text { - Cirrhosis }\end{array}$ \\
\hline
\end{tabular}

*Assessment of liver disease is recommended if the patient is 40 years or older.

${ }^{\dagger}$ Assessment of liver disease is recommended if the patient is 30 years or older. Biopsy is to be considered in patients of older age and/or with fluctuating/minimally elevated alanine aminotransferase (ALT) concentrations or family history of hepatocellular carcinoma.

AASLD, American Association for the Study of Liver Diseases; APASL, Asian Pacific Association for the Study of the Liver; EASL, European Association for the Study of the Liver; HBeAg, hepatitis B e antigen; HBV, hepatitis B virus; ULN, upper limit of normal. 
Figure 1. Treatment algorithm for patients with chronic hepatitis B (CHB) who have hepatitis B e antigen (HBeAg)positive disease (A), HBeAg-negative disease (B), or cirrhosis (C). The strength of all recommendations is A (based on guidelines for management of CHB from the American Association for the Study of Liver Diseases, the European Association for the Study of the Liver, and the Asian Pacific Association for the Study of the Liver ${ }^{10-12}$ ). Alanine aminotransferase (ALT) upper limit of normal (ULN): $19 \mathrm{IU} / \mathrm{mL}$ in women, $30 \mathrm{IU} / \mathrm{mL}$ in men. Sensitive real-time polymerase chain reaction (PCR): lower limit of detection, $\sim 5-10 \mathrm{IU} / \mathrm{mL}$; lower limit of quantification, $\sim 30 \mathrm{IU} / \mathrm{mL}$. *See the text for definition of patients at high risk of hepatocellular carcinoma (HCC). ETV, entecavir; HBV, hepatitis B virus; Peg-IFN- $\alpha$, pegylated interferon- $\alpha$; TDF, tenofovir.

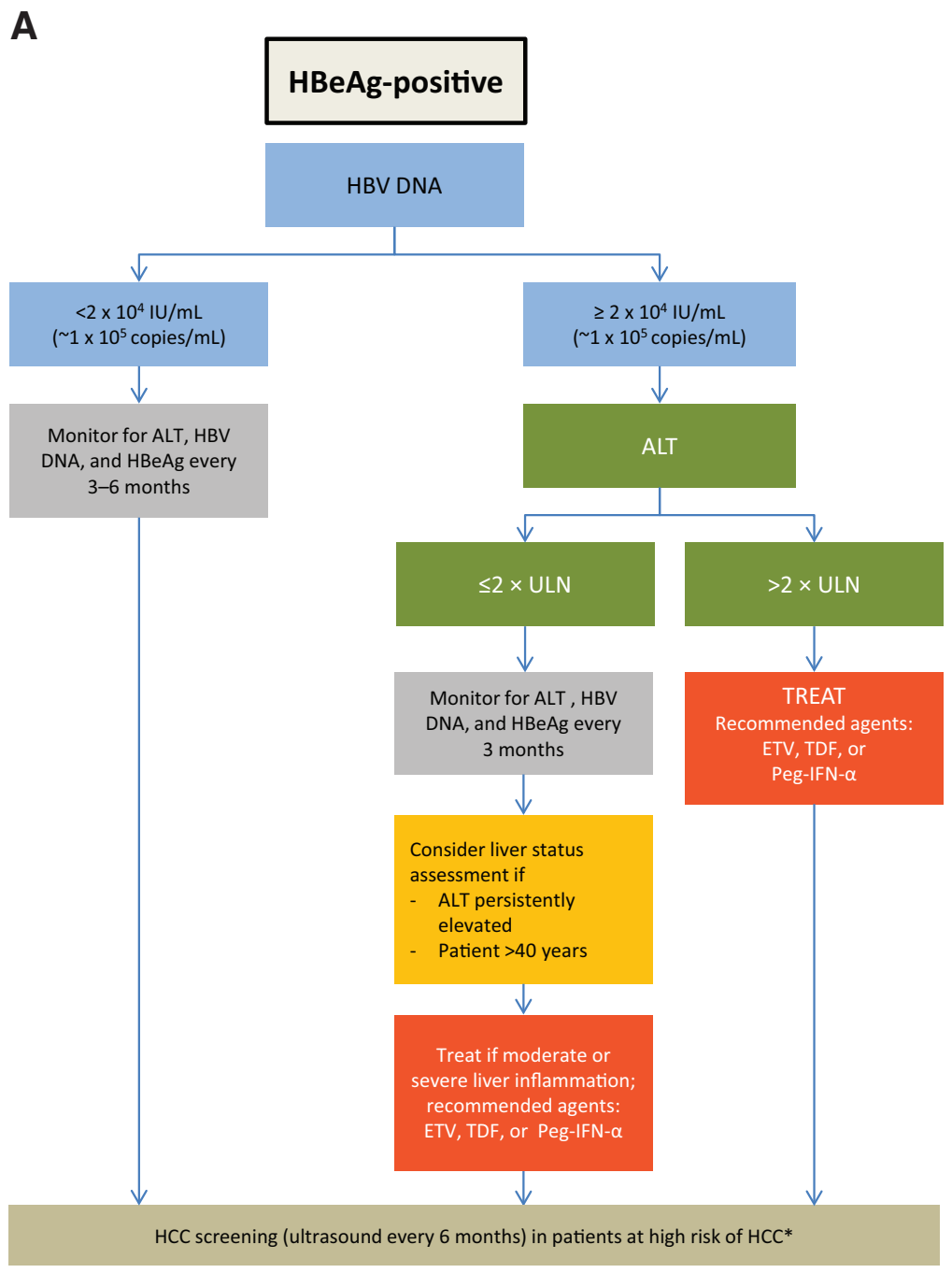

ommendations by AASLD, APASL, and EASL, and incorporating our experience and opinion.

In real-life practice, patients with CHB may present with coexisting morbidities such as advanced liver disease or coinfection with human immunodeficiency virus, hepatitis $\mathrm{C}$ virus, or hepatitis $\mathrm{D}$ virus, or they may have other special circumstances such as liver transplantation, undergoing immune-suppressive therapy, or pregnancy. In these cases, specific issues need to be considered, and special management strategies are required (Table 3 ).
For patients in whom antiviral therapy for $\mathrm{CHB}$ is indicated, the currently approved agents are interferons (IFNs) and NUCs (Table 4). IFNs (IFN- $\alpha$ and pegylated IFN- $\alpha$ ), which historically were the first available treatments for CHB, stimulate immune-mediated suppression of $\mathrm{HBV}$ and achieve higher HBeAg seroconversion rates than NUCs after 1 year $(\sim 30 \%)^{12}$; however, they have more adverse side effects than NUCs, are administered by subcutaneous injection, and are effective in a select minority $(\sim 30 \%)$ of all patients requiring therapy 
Figure 1. Continued

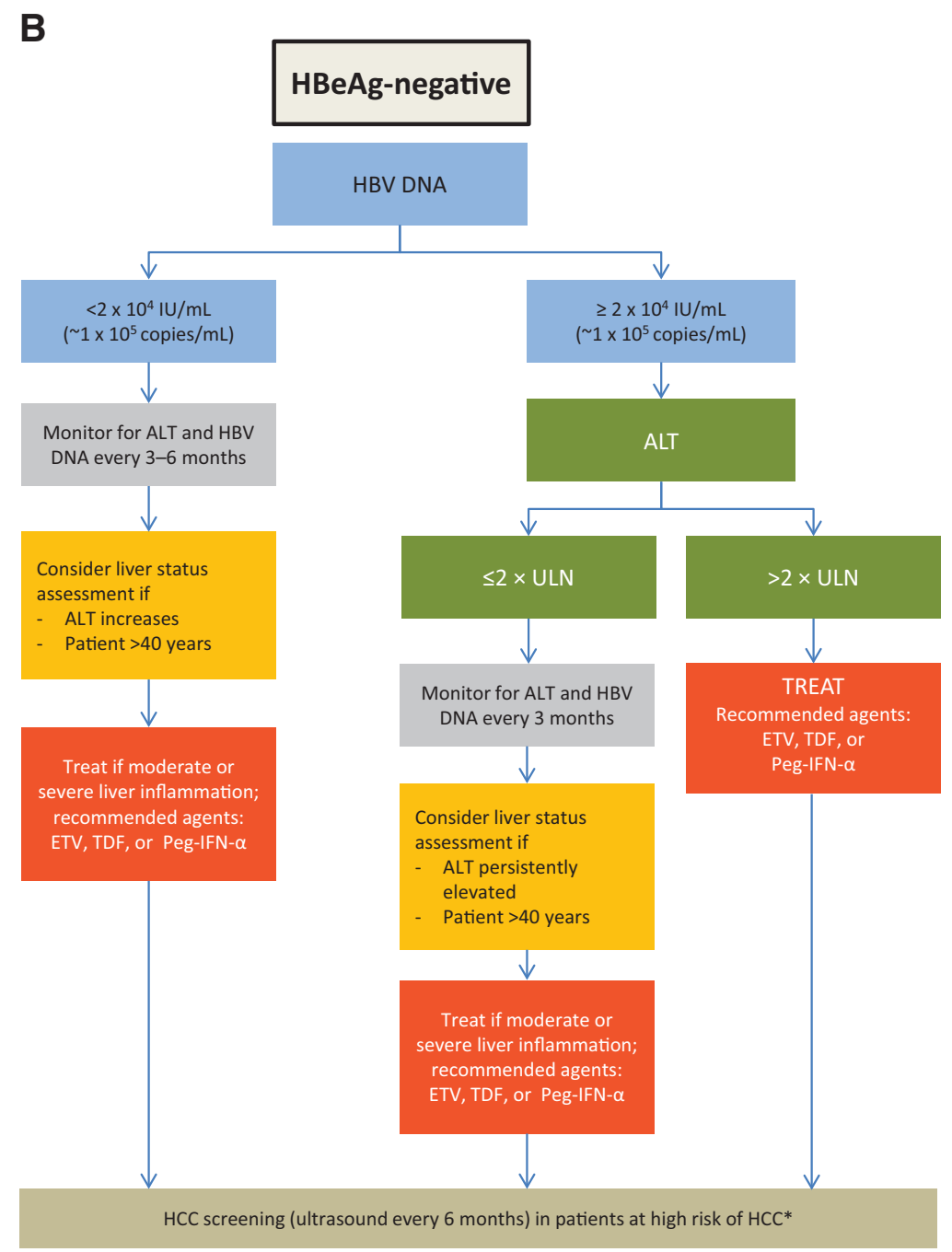

(HBeAg-positive patients with high ALT and low HBV DNA at baseline). ${ }^{10,11}$ Furthermore, IFNs are contraindicated in patients with decompensated cirrhosis, in whom there is increased risk of liver failure and sepsis; in patients with autoimmune diseases, bone-marrow disorders, or uncontrolled psychiatric disorders; and during pregnancy. ${ }^{10-12}$ For these reasons, the use of IFNs in CHB treatment has declined with the availability of NUCs.

NUCs are oral agents and generally are better tolerated than IFNs, allowing for prolonged use. Compared with IFNs, NUCs are effective in most patients and achieve higher rates of $\mathrm{HBV}$ DNA suppression. Compared with IFNs, HBeAg seroconversion rates with NUCs are lower after 1 year $(\sim 20 \%)^{12}$ but may reach $\sim 40 \%$ to $50 \%$ with continued NUC therapy. ${ }^{38,44}$ During long- term NUC therapy, however, drug resistance may develop. ${ }^{10-12}$ Among the approved NUCs, the nucleoside analog entecavir (ETV) and the nucleotide analog tenofovir (TDF) are currently the preferred first-line agents; both are potent compounds with high barriers to resistance $(\leq 1 \%$ during long-term therapy). ${ }^{10-12}$ Other approved NUCs include the nucleoside analogs telbivudine and lamivudine (LVD), and the nucleotide analog adefovir; however, these older NUCs have higher rates of resistance and are no longer recommended for use as first-line monotherapy. ${ }^{10-12}$ Nucleoside and nucleotide analogs generally have nonoverlapping resistance profiles, which is an important factor to consider when managing patients who develop drug resistance (see Treatment Failure and HBV Resistance on NUC Therapy). 


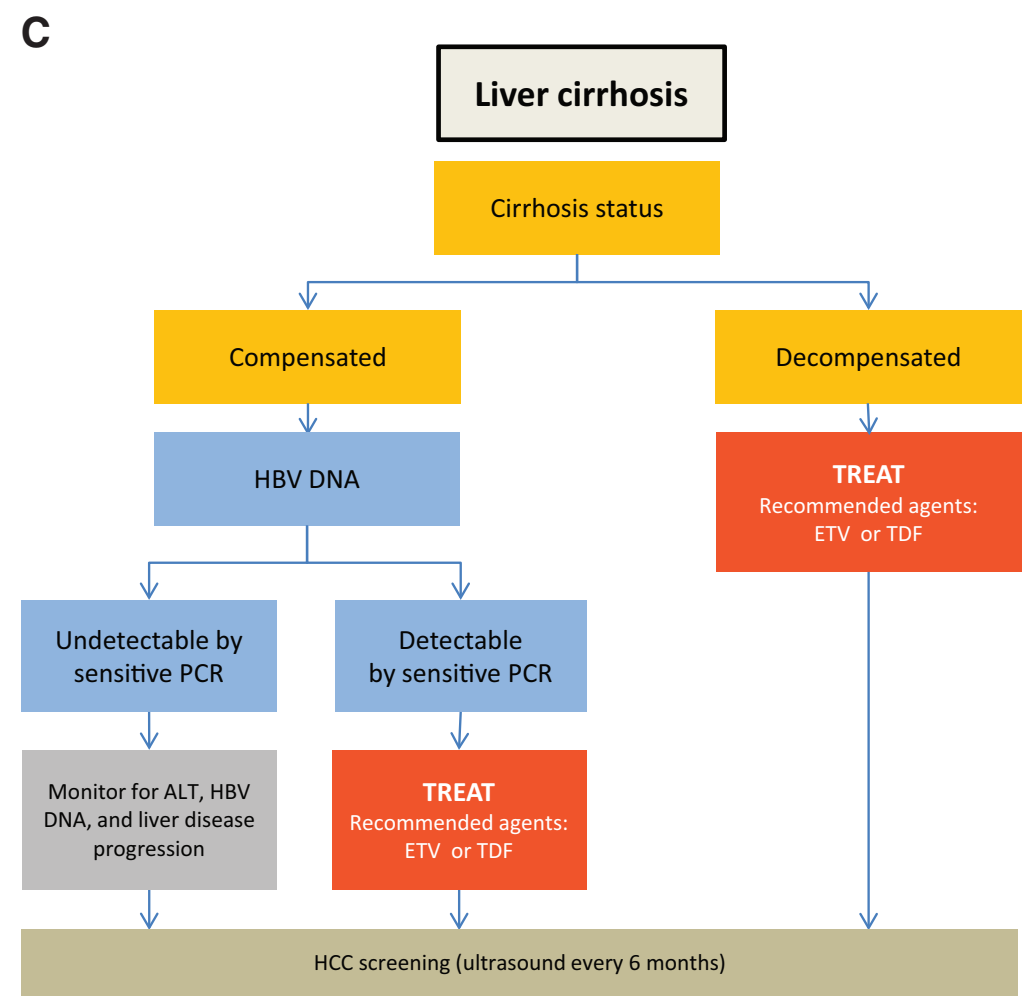

\section{Special Considerations and Unresolved Issues in CHB Management \\ Treatment Eligibility}

In real-life practice, the decision of whether to initiate HBV therapy may not always be straightforward. For example, among patients without detectable $\mathrm{HBeAg}$, it may be difficult to distinguish true inactive carriers, who do not require treatment, from patients with $\mathrm{HBeAg}$-negative $\mathrm{CHB}$, who require treatment. HBV DNA and ALT should be monitored regularly every 3 to 12 months for at least 3 years ${ }^{10-12}$ to detect any fluctuations indicative of HBeAg-negative CHB. ${ }^{12} \mathrm{HBV}$ genotyping can be used to detect $\mathrm{PC} / \mathrm{BCP}$ variants that are more prevalent in $\mathrm{HBeAg}$-negative CHB.

Furthermore, quantitative $\mathrm{HBsAg}$ (qHBsAg) measurement, combined with HBV DNA, may prove useful in the future, as qHBsAg levels have been found to be the lowest among inactive carriers (see Table 1). In a study of patients with undetectable HBeAg and HBV genotype $\mathrm{D}$, qHBsAg $<1000 \mathrm{IU} / \mathrm{mL}$ and HBV DNA $\leq 2000 \mathrm{IU} / \mathrm{mL}$ could accurately identify the inactive carrier state in $90 \%$ of the patients ${ }^{45}$; however, quantitative
$\mathrm{HBsAg}$ measurement is not routinely performed in most US practices.

Another difficulty relates to the variation in specific criteria for initiating antiviral therapy between the different societal guidelines. For example, although all 3 guidelines recommend treatment in HBeAg-negative patients with ALT $>2$ times the ULN and elevated HBV DNA, the HBV DNA threshold to start treatment is $>20,000 \mathrm{IU} / \mathrm{mL}$ in the US and European guidelines, ${ }^{10,12}$ but $>2000 \mathrm{IU} / \mathrm{mL}$ in the Asian guidelines. ${ }^{11}$ Similarly, in $\mathrm{HBeAg}$ positive patients with minimally elevated ALT (ALT $>1$ but $<2$ times the ULN), histologic evaluation is recommended in patients with $\mathrm{HBV}$ DNA $>2000 \mathrm{IU} / \mathrm{mL}$ and age $\geq 30$ years in the European guidelines, ${ }^{12}$ whereas it is HBV DNA $>20,000 \mathrm{IU} / \mathrm{mL}$ and age $\geq 40$ years in the US and Asian guidelines. ${ }^{10,11}$ These variations may be explained in part by geographic differences in disease characteristics. For example, HCC risk is greater among Asian than among Western patients, particularly those with $\mathrm{HBeAg}$-negative disease, ${ }^{46}$ and even in the absence of cirrhosis. ${ }^{47}$ The recommendations may also vary because of 
Table 3. Recommendations for the Management of Chronic Hepatitis B Infection in Special Patient Populations

\begin{tabular}{|c|c|c|}
\hline Patient Population & Key Issues & Recommendations \\
\hline Decompensated liver disease* & $\begin{array}{l}\text { - Higher risk of cirrhosis, HCC, and } \\
\text { mortality } \\
\text { - Often associated with } \\
\text { comorbidities such as renal } \\
\text { dysfunction, protein malnutrition, } \\
\text { or vitamin deficiencies }\end{array}$ & $\begin{array}{l}\text { - Treatment is indicated irrespective of HBV DNA } \\
\text { levels to improve clinical status } \\
\text { - Recommended agents: ETV and TDF (well } \\
\text { tolerated and shown to improve liver status) } \\
\text { - Regular monitoring of renal function and lactic } \\
\text { acidosis recommended during ETV or TDF } \\
\text { therapy } \\
\text { - IFNs contraindicated; they may increase risk of } \\
\text { sepsis and decompensation }\end{array}$ \\
\hline $\begin{array}{l}\mathrm{HCV}, \mathrm{HDV}, \text { or HIV } \\
\text { coinfection }\end{array}$ & $\begin{array}{l}\text { - Multiple viruses to be managed } \\
\text { - Higher risk of cirrhosis, HCC, and } \\
\text { mortality }\end{array}$ & $\begin{array}{l}\text { - Treatment should target the dominant virus } \\
\text { - In HIV coinfection, LVD and TDF are active } \\
\text { against both HBV and HIV; ETV is not } \\
\text { recommended unless the patient also receives } \\
\text { HAART } \\
\text { - Peg-IFN only drug effective against HDV } \\
\text { - Some reports of renal toxicity with TDF in } \\
\text { HBV/HIV-coinfected patients }\end{array}$ \\
\hline LT recipients & - Risk of HBV reactivation & $\begin{array}{l}\text { - Anti-HBV prophylaxis before and/or after LT } \\
\text { recommended } \\
\text { - HBIg with or without LVD historically is the } \\
\text { most common approach; however, there is no } \\
\text { consensus on HBIg dose and duration (that is, } \\
\text { long-term low dose vs. short-term high dose; } \\
\text { HBIg withdrawal; on-demand HBIg on NUC } \\
\text { maintenance) } \\
\text { - Alternative prophylactic regimens: ETV or TDF, } \\
\text { alone or combined with HBIg }\end{array}$ \\
\hline $\begin{array}{l}\text { Immune-suppressive or } \\
\text { chemotherapy }\end{array}$ & - Risk of HBV reactivation & $\begin{array}{l}\text { - In HBsAg-positive patients, preemptive NUC } \\
\text { therapy should be initiated at the onset of } \\
\text { immunesuppressive or chemotherapy to prevent } \\
\text { HBV reactivation } \\
\text { - In anti-HBc-positive patients receiving rituximab, } \\
\text { anti-HBV prophylaxis is recommended }\end{array}$ \\
\hline Pregnancy & $\begin{array}{l}\text { - Risk of perinatal infection from } \\
\text { highly viremic mothers } \\
\text { - Risk of fetal damage }\end{array}$ & $\begin{array}{l}\text { - IFN-based therapy is contraindicated because of } \\
\text { its antiproliferative effect } \\
\text { - LdT and TDF are classified as category B (no } \\
\text { risk in animal studies but unknown in humans) } \\
\text { - LVD, ADV, and ETV are classified as category } \\
\text { C (teratogenic in animals, unknown in humans) }\end{array}$ \\
\hline Pediatric patients & $\begin{array}{l}\text { - Infection at an early age is } \\
\text { associated with an increased risk of } \\
\text { long-term complications } \\
\text { - Long-term safety and drug } \\
\text { resistance are important concerns }\end{array}$ & $\begin{array}{l}\text { - Recommended to initiate treatment if ALT } \\
\text { persistently }>2 \times \text { ULN } \\
\text { - IFNs given parenterally and associated with } \\
\text { temporarily disrupted growth }{ }^{43}\end{array}$ \\
\hline
\end{tabular}

Data compiled from refs. $10-12$.

${ }^{*}$ Defined as child B or C cirrhosis, or Child-Turcotte-Pugh score $\geq 7$.

ADV, adefovir; ALT, alanine aminotransferase; ETV, entecavir; HAART, highly active antiretroviral therapy; HBc, hepatitis B core antigen; $\mathrm{HBIg}$, hepatitis B immunoglobulin; HBsAg, hepatitis B s antigen; HBV, hepatitis B virus; $\mathrm{HCC}$, hepatocellular carcinoma; HCV, hepatitis C virus; HDV, hepatitis D virus; HIV, human immunodeficiency virus; IFN, interferon; LdT, telbivudine; LT, liver transplant; LVD, lamivudine; NUC, nucleo(s)tide analog; Peg-IFN, pegylated interferon; TDF, tenofovir; ULN, upper limit of normal.

geographic differences in the perceptions of physicians as well as differences in publication dates.

Another controversial issue concerning treatment eligibility is whether the current criteria adequately identify all patients with $\mathrm{CHB}$ who are at risk of liver disease progression. For example, treatment is not recommended for patients with HBV DNA <2000 IU/mL; however, it has recently been shown that $\mathrm{HBeAg-negative} \mathrm{pa-}$ tients with $\mathrm{HBV}$ DNA $<2000 \mathrm{IU} / \mathrm{mL}$ but with $\mathrm{qHBsAg} \geq 1000 \mathrm{IU} / \mathrm{mL}$ have a 14 times higher HCC risk than those with $\mathrm{qHBsAg}<1000 \mathrm{IU} / \mathrm{mL}$. ${ }^{48}$ Another group of patients for whom treatment is not recommended are $\mathrm{HBeAg}$-negative patients with high HBV DNA and low/normal ALT; however, persistently elevated HBV DNA has been clearly established as an important HCC risk factor in these patients. ${ }^{24-26}$ Family history 


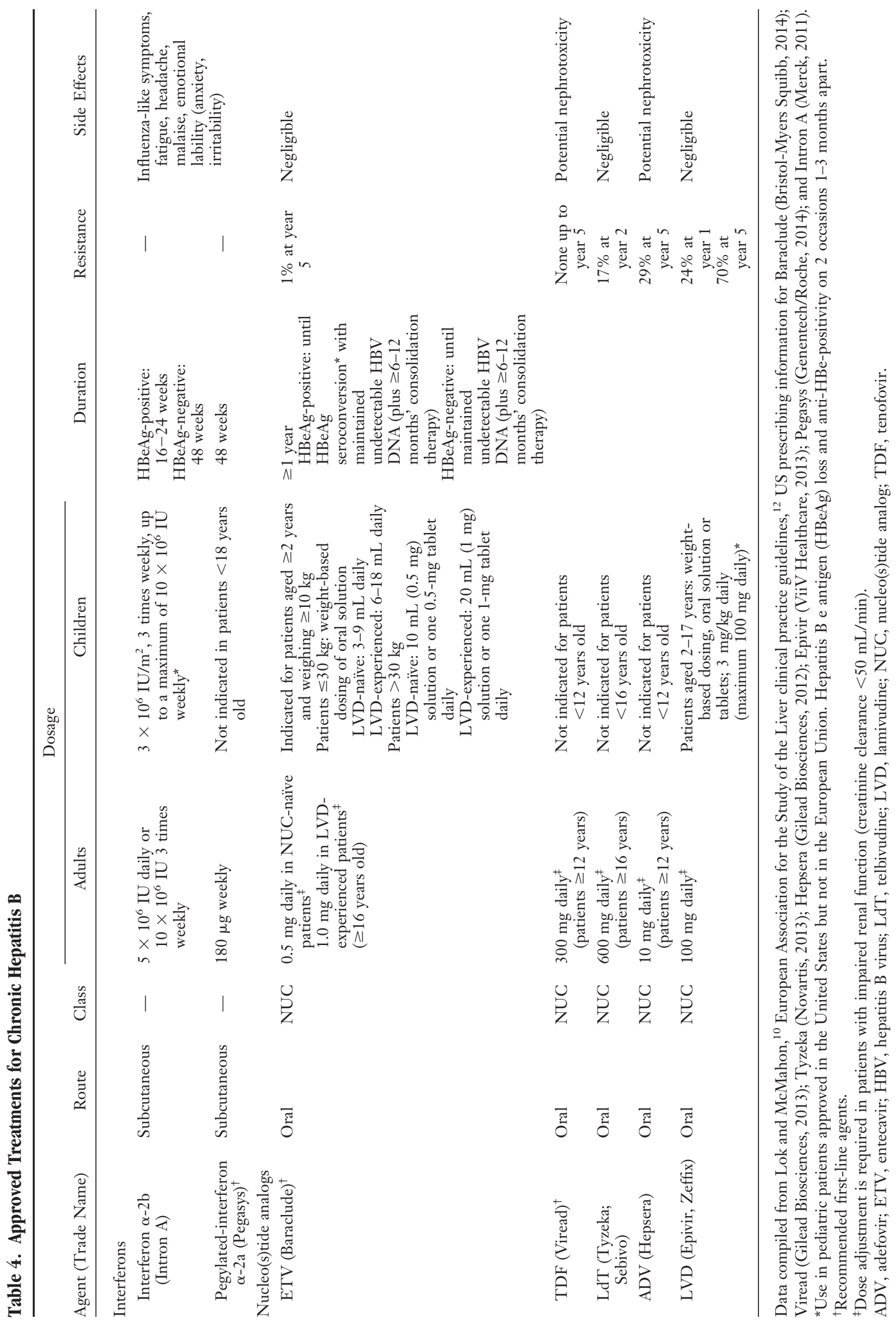


of liver disease is another risk factor for HBVrelated liver complications and may also be taken into account when considering treatment. ${ }^{10-12}$ Whether treatment indications should be extended to include these patients requires careful consideration of the benefit provided by treatment, such as decreased risk of cirrhosis and HCC, versus the risks of long-term treatment, such as side effects, resistance development, and increased cost.

\section{Treatment Failure and HBV Resistance on NUC Therapy}

An important point to consider with NUC-based therapy is treatment failure (ie, partial virologic response [HBV DNA decrease $>1 \log _{10} \mathrm{IU} / \mathrm{mL}$ after 6 or 12 months of treatment but still detectable], primary nonresponse [HBV DNA decrease $<1-2 \log _{10}$ IU/mL after 3 to 6 months of therapy], or virologic breakthrough [HBV DNA increase $>1 \log _{10} \mathrm{IU} / \mathrm{mL}$ above nadir after achieving a virologic response ${ }^{10-12}$ ). Treatment failure can be the result of drug resistance; however, compliance should be ascertained, since with the current first-line agents ETV and TDF, development of resistance is rare. In compliant patients, $\mathrm{HBV}$ genotyping for identifying possible resistance mutations may guide further treatment decisions. In the case of resistance, the guidelines recommend either switching to or adding a more potent agent with a nonoverlapping resistance profile. Compared with sequential monotherapy, combination therapy may provide greater protection against multidrug resistance; however, there is no clear consensus regarding an optimal rescue strategy. For example, for patients with LVD resistance, which accounts for most cases of $\mathrm{HBV}$ resistance, the US and Asian guidelines recommend adding on TDF or adefovir, ${ }^{10,11}$ whereas the European guidelines recommend either adding on or switching to TDF. ${ }^{12}$ ETV monotherapy is generally not suitable for patients with LVD resistance because the 2 agents have crossresistance, with LVD resistance predisposing for ETV resistance. ${ }^{49}$ Other rescue strategies, such as adding on $\mathrm{ETV}^{50}$ or switching to ETV plus TDF combination therapy, ${ }^{51}$ have also been shown to be effective in patients in whom prior NUC therapy has failed and therefore represent alternative treatment options. For patients with a partial virologic response when taking high-bar- rier-to-resistance NUCs such as ETV or TDF, there is also evidence showing that continued monotherapy with the same agent often eventually results in complete virologic suppression (with minimal resistance development), obviating the need for treatment changes. ${ }^{52-54}$

\section{Treatment Duration and Stopping Rules}

For NUC-based antiviral therapy, the guidelines stipulate that treatment can be stopped after achieving certain end points that reflect the patient's HBeAg status and degree of liver fibrosis. In $\mathrm{HBeAg}$-positive patients, the recommended end points are $\mathrm{HBeAg}$ seroconversion following sustained undetectable HBV DNA with ALT normalization; in $\mathrm{HBeAg}$-negative patients or $\mathrm{HBeAg}$ positive patients who do not seroconvert, the recommended end points are sustained undetectable HBV DNA with ALT normalization. ${ }^{10-12}$ Consolidation therapy is recommended in patients who achieve these end points, but there is no consensus on its optimal duration (6 or 12 months or longer). ${ }^{10-12}$ Ultimately, HBsAg loss is the ideal end point because it is associated with a significantly reduced HCC risk, although not as low as that of a person who has never been infected with $\mathrm{HBV}^{30}$

However, achievement of these end points is rare with 4 to 5 years of treatment ( $40 \%$ to $52 \%$ for $\mathrm{HBeAg}$ seroconversion, ${ }^{38,44} \leq 10 \%$ for $\mathrm{HBsAg} \operatorname{loss}^{23}$ ), and there is also growing evidence suggesting that it does not guarantee long-term remission. This is because of the presence of covalently closed circular HBV DNA (cccDNA) inside the nuclei of infected hepatocytes, which is the stable genetic component of HBV that may persist even after HBsAg loss has occurred, thereby allowing HBV reactivation. ${ }^{21,55}$ Thus, even with consolidation therapy, HBV recurrence is frequent, with $\sim 40 \%$ to $80 \%$ of patients experiencing virologic relapse after stopping therapy. ${ }^{56-61}$ Therefore, in clinical practice, a considerable proportion of patients will require long-term, if not indefinite, treatment with NUCs to maintain these end points and prevent $\mathrm{HBV}$ reactivation.

IFN-based therapy is administered over a finite duration (usually 48 weeks), irrespective of achievement of these end points, since prolonged maintenance therapy to suppress HBV replication is not feasible with these regimens. ${ }^{62}$ 


\section{Role of Noninvasive Assessment of Liver Disease}

The societal guidelines all recommend assessment of liver histology in certain groups of patients to guide decisions on treatment initiation ${ }^{10-12}$ (see Table 2). However, because routine assessment of liver fibrosis and cirrhosis using liver biopsy is difficult in clinical practice, other noninvasive assessments have been developed that could be used as a substitute. Transient elastography (FibroScan), which measures liver stiffness, has been shown to be an accurate tool for assessing liver disease in patients with either a very high or very low risk of fibrosis ${ }^{63}$; however, it might overestimate fibrosis in patients with elevated ALT. ${ }^{64}$ Other noninvasive tests for fibrosis are FibroSpect and FibroSure, which measure serum markers that correlate with the degree of liver damage, such as $\alpha$-2-macroglobulin, total bilirubin, apolipoprotein $\mathrm{A} 1$, and hyaluronic $\operatorname{acid}^{27,28}$; however, further studies are needed to evaluate these tools in CHB management.

\section{HCC Screening and the Role of HCC Risk Scores}

CHB is associated with a higher risk of HCC, and HCC incidences among untreated patients range from $0.3 \%$ to $0.6 \%$ in those without cirrhosis and $2.2 \%$ to $3.7 \%$ in those with compensated cirrhosis. ${ }^{65}$ Recent data indicate that with the current potent NUCs, the risk of HCC risk can be reduced but not completely eliminated. ${ }^{66}$ Thus regular HCC surveillance is recommended even in patients receiving anti-HBV treatment, and it has been shown to be a cost-effective strategy in CHB management. ${ }^{67}$ The AASLD Practice Guidelines for Management of HCC recommend ultrasound every 6 months for HCC screening; $\alpha$-fetoprotein, which has long been used for HCC diagnosis as well, has been shown to be insufficiently sensitive and specific for use as a surveillance assay. ${ }^{67}$ The AASLD and APASL CHB Practice Guidelines recommend screening all $\mathrm{HBV}$ carriers at high risk of $\mathrm{HCC}$, that is, Asian men $>40$ years and Asian women $>50$ years of age, patients with cirrhosis or with a family history of HCC, Africans $>20$ years of age, and any carrier $>40$ years old with persistent or intermittent ALT elevation and/or high HBV DNA level $(>2,000 \mathrm{IU} / \mathrm{mL}) .{ }^{10-12}$ Several HCC risk calculators have recently been developed to estimate a patient's future risk of developing
HBV-related HCC. ${ }^{68-71}$ These scores incorporate various combinations of established HCC risk factors (eg, age, sex, HBV DNA level, or markers of liver function), many of which can be assessed in clinical practice and might prove useful to identify patients most in need of HCC screening.

\section{Directions for Future Research cccDNA Elimination}

Elimination of cccDNA is assumed to lower the risk of $\mathrm{HBV}$ reactivation after seroclearance and may also reduce the risk of HCC. ${ }^{55,72,73}$ Current antiviral therapies target the synthesis of serum HBV DNA but not cccDNA ${ }^{21}$; however, there is evidence suggesting that cccDNA levels can also be reduced to some degree with NUCs, ${ }^{74-76}$ but more studies are needed to confirm these findings. Combination therapy plus IFNs and NUCs may result in a greater reduction in cccDNA levels, ${ }^{77}$ possibly as a result of an immune-modulatory attack of infected hepatocytes. ${ }^{70}$ New agents that directly inhibit cccDNA formation by interfering with the conversion of precursor relaxed circular DNA to mature cccDNA are currently being developed. ${ }^{78}$

\section{qHBsAg as a New Marker of Treatment Efficacy}

Serum concentrations of qHBsAg, which reflect levels of cccDNA in the liver, vary during the course of $\mathrm{CHB}$; they are highest in the immunetolerant phase, followed by a decline during the immune clearance phase and a further decrease after HBeAg seroconversion, becoming lowest in inactive carriers. With IFN-based antiviral therapy, a rapid reduction in $\mathrm{qHBsAg}$ is predictive of a sustained response; thus, an "early stopping rule" has been proposed, suggesting that IFN therapy can be stopped or switched by week 12 in patients without qHBsAg decline because they are unlikely to achieve a response with further IFN treatment. ${ }^{79}$ In NUC-based therapy, the clinical relevance of qHBsAg is less well defined. qHBsAg reductions are generally less pronounced with NUCs compared with IFNs, and the data regarding a potential association of $\mathrm{qHBsAg}$ with serologic or virologic responses are inconsistent. ${ }^{79}$ Thus, more research is needed to understand $\mathrm{qHBsAg}$ kinetics during NUC therapy and allow potential tailoring of treatment duration to individual patients. 


\section{New Treatments for CHB}

Neither IFNs nor NUCs are capable of completely eliminating the virus; thus there is a need for new treatments that might provide greater benefit. The combination of 2 potent NUCs might have additive or synergistic antiviral activity, which may result in faster or more profound viral suppression. However, the antiviral efficacy of ETV plus TDF was found to be comparable to that of ETV monotherapy, although it did show an incremental benefit in HBeAg-positive patients with baseline levels of HBV DNA $\geq 10^{8} \mathrm{IU} / \mathrm{mL} .{ }^{80}$ The combination of IFN plus NUC may stimulate immunologic responses in patients with NUC-induced virologic suppression, thereby potentially achieving a sustained response with a finite treatment duration. Indeed, in patients with maintained undetectable HBV DNA on ETV, the addition of or switch to pegylated IFN- $\alpha$ resulted in significantly higher rates of HBeAg seroconversion and HBsAg clearance than continuing on ETV alone, ${ }^{81,82}$ indicating that this may be a new treatment strategy. An alternative approach for immune-mediated treatment of CHB is therapeutic vaccination. This modality, which is different from prophylactic vaccination, aims to boost $\mathrm{HBV}$-specific T-cell responses, which are generally deficient in patients with $\mathrm{CHB}$, and has the potential to be a cheap and effective treatment option. A number of therapeutic vaccines based on viral envelope or capsid antigens or HBV DNA have been developed; however, so far they have demonstrated limited clinical efficacy. ${ }^{83}$

Bibliographic and editorial assistance was provided by Isabelle Kaufmann of ArticulateScience UK and was supported by a grant from Bristol-Myers Squibb.

\section{References}

1. World Health Organization. Hepatitis B. Fact sheet no. 204. Updated 2015. Available from: http:// www.who.int/mediacentre/factsheets/fs2 04/en/. Accessed September 18, 2015.

2. Lozano R, Naghavi M, Foreman K, et al. Global and regional mortality from 235 causes of death for 20 age groups in 1990 and 2010: a systematic analysis for the Global Burden of Disease Study 2010. Lancet 2012;380:2095-128.

3. Ioannou GN. Hepatitis B virus in the United States: infection, exposure, and immunity rates in a nationally representative survey. Ann Intern Med 2011; 154:319-28.
4. Hosaka T, Suzuki F, Kobayashi M, et al. Long-term entecavir treatment reduces hepatocellular carcinoma incidence in patients with hepatitis $B$ virus infection. Hepatology 2013;58:98-107.

5. Zoutendijk R, Reijnders JG, Zoulim F, et al. Virological response to entecavir is associated with a better clinical outcome in chronic hepatitis B patients with cirrhosis. Gut 2013;62:760-5.

6. Wong GL, Chan HL, Mak CW, et al. Entecavir treatment reduces hepatic events and deaths in chronic hepatitis B patients with liver cirrhosis. Hepatology 2013;58:1537-47.

7. Lim YS, Han S, Heo NY, Shim JH, Lee HC, Suh DJ. Mortality, liver transplantation, and hepatocellular carcinoma among patients with chronic hepatitis B treated with entecavir vs lamivudine. Gastroenterology 2014;147:152-61.

8. Wu CY, Lin JT, Ho HJ, et al. Association of nucleos(t)ide analogue therapy with reduced risk of hepatocellular carcinoma in patients with chronic hepatitis B-a nationwide cohort study. Gastroenterology 2014;147: 143-51.e5.

9. Gordon SC, Lamerato LE, Rupp LB, et al. Antiviral therapy for chronic hepatitis B virus infection and development of hepatocellular carcinoma in a US population. Clin Gastroenterol Hepatol 2014;12: 885-93.

10. Lok AS, McMahon BJ. Chronic hepatitis B: update 2009. Hepatology 2009;50:661-2.

11. Liaw YF, Kao JH, Piratvisuth T, et al. AsianPacific consensus statement on the management of chronic hepatitis B: a 2012 update. Hepatol Int 2012;6:531-61.

12. European Association for the Study of the Liver. EASL clinical practice guidelines: management of chronic hepatitis B virus infection. J Hepatol 2012; 57:167-85.

13. Han SH, Jing W, Mena E, et al. Adherence, persistence, healthcare utilization, and cost benefits of guideline-recommended hepatitis B pharmacotherapy. J Med Econ 2012;15:1159-66.

14. Wu Y, Johnson KB, Roccaro H, et al. Poor adherence to AASLD guidelines for chronic hepatitis B management in a large academic medical center. Am J Gastroenterol 2014;109:867-75.

15. Burman BE, Mukhtar NA, Toy BC, et al. Hepatitis B management in Vulnerable populations: gaps in disease monitoring and opportunities for improved care. Dig Dis Sci 2013;59:46-56.

16. Juday T, Tang H, Harris M, Powers AZ, Kim E, Hanna GJ. Adherence to chronic hepatitis B treatment guideline recommendations for laboratory monitoring of patients who are not receiving antiviral treatment. J Gen Intern Med 2011;26:239-44.

17. Ku KC, Li J, Ha NB, Martin M, Nguyen VG, Nguyen $\mathrm{MH}$. Chronic hepatitis B management based on standard guidelines in community primary care and specialty clinics. Dig Dis Sci 2013;58:3626-33. 
18. Upadhyaya N, Chang R, Davis C, Conti MC, Salinas-Garcia D, Tang H. Chronic hepatitis B: perceptions in Asian American communities and diagnosis and management practices among primary care physicians. Postgrad Med 2010;122:165-75.

19. Les I, Garcia-Martinez R, Cordoba J, Quintana M, Esteban R, Buti M. Current trends in chronic hepatitis $B$ management: results of a questionnaire. Eur J Gastroenterol Hepatol 2009;21:1177-83.

20. Ning LH, Hao J, Liao ZL, Zhou YY, Guo H, Zhao $\mathrm{XY}$. A survey on the current trends in the management of hepatitis B in China. Eur J Gastroenterol Hepatol 2012;24:884-9.

21. Liang TJ. Hepatitis B: the virus and disease. Hepatology 2009;49:S13-S21.

22. Liaw YF. Natural history of chronic hepatitis B virus infection and long-term outcome under treatment. Liver Int 2009;29(Suppl 1):100-7.

23. Kwon H, Lok AS. Hepatitis B therapy. Nat Rev Gastroenterol Hepatol 2011;8:275-84.

24. Chen CJ, Yang HI, Su J, et al. Risk of hepatocellular carcinoma across a biological gradient of serum hepatitis B virus DNA level. JAMA 2006;295:65-73.

25. Chan HL, Tse CH, Mo F, et al. High viral load and hepatitis $\mathrm{B}$ virus subgenotype ce are associated with increased risk of hepatocellular carcinoma. J Clin Oncol 2008;26:177-82.

26. Chen G, Lin W, Shen F, Iloeje UH, London WT, Evans AA. Past HBV viral load as predictor of mortality and morbidity from HCC and chronic liver disease in a prospective study. Am J Gastroenterol 2006;101:1797-803.

27. Zaman A, Rosen HR, Ingram K, Corless CL, Oh E, Smith K. Assessment of FIBROSpect II to detect hepatic fibrosis in chronic hepatitis $\mathrm{C}$ patients. Am J Med 2007;120:280.e9-14.

28. Naveau S, Gaude G, Asnacios A, et al. Diagnostic and prognostic values of noninvasive biomarkers of fibrosis in patients with alcoholic liver disease. Hepatology 2009;49:97-105.

29. Liaw YF. HBeAg seroconversion as an important end point in the treatment of chronic hepatitis B. Hepatol Int 2009;3:425-33.

30. Chu CM, Liaw YF. Hepatitis B surface antigen seroclearance during chronic $\mathrm{HBV}$ infection. Antivir Ther 2010;15:133-43.

31. Chen YC, Chu CM, Liaw YF. Age-specific prognosis following spontaneous hepatitis B e antigen seroconversion in chronic hepatitis B. Hepatology 2010; 51:435-44.

32. Funk ML, Rosenberg DM, Lok AS. World-wide epidemiology of HBeAg-negative chronic hepatitis B and associated precore and core promoter variants. J Viral Hepat 2002;9:52-61.

33. Mitchell AE, Colvin HM, Palmer Beasley R. Institute of Medicine recommendations for the prevention and control of hepatitis B and C. Hepatology 2010;51:729-33.
34. Hatzakis A, Wait S, Bruix J, et al. The state of hepatitis $\mathrm{B}$ and $\mathrm{C}$ in Europe: report from the hepatitis $\mathrm{B}$ and $\mathrm{C}$ summit conference. J Viral Hepat 2011;18(Suppl 1):1-16.

35. LeFevre ML; U.S. Preventive Services Task Force. Screening for hepatitis B virus infection in nonpregnant adolescents and adults: U.S. Preventive Services Task Force recommendation statement. Ann Intern Med 2014;161:58-66.

36. $\mathrm{Hu} \mathrm{KQ}$, Pan CQ, Goodwin D. Barriers to screening for hepatitis B virus infection in Asian Americans. Dig Dis Sci 2011;56:3163-71.

37. Averhoff F. Yellowbook. Chapter 3: Infectious diseases related to travel. July 10, 2015. Atlanta: Centers for Disease Control and Prevention. Available from: http://wwwnc.cdc.gov/travel/yellowbook/2016/ infectious-diseases-related-to-travel/hepatitis-b. Accessed September 18, 2015.

38. Marcellin P, Gane E, Buti M, et al. Regression of cirrhosis during treatment with tenofovir disoproxil fumarate for chronic hepatitis B: a 5-year open-label follow-up study. Lancet 2012;38:468-75.

39. Shim JH, Lee HC, Kim KM, et al. Efficacy of entecavir in treatment-naive patients with hepatitis $\mathrm{B}$ virus-related decompensated cirrhosis. J Hepatol 2010;52:176-82.

40. Schiff ER, Lee SS, Chao YC, et al. Long-term treatment with entecavir induces reversal of advanced fibrosis or cirrhosis in patients with chronic hepatitis B. Clin Gastroenterol Hepatol 2011;9:274-6.

41. Han K-H, Kim DY. Chronic HBV infection with persistently normal ALT b. not to treat. Hepatol Int 2008;2:185-9.

42. Chan HL, Chan CK, Hui AJ, et al. Effects of tenofovir disoproxil fumarate in hepatitis B e antigenpositive patients with normal levels of alanine aminotransferase and high levels of hepatitis $B$ virus DNA. Gastroenterology 2014;146:1240-8.

43. Comanor L, Minor J, Conjeevaram HS, et al. Impact of chronic hepatitis B and interferon-alpha therapy on growth of children. J Viral Hepat 2001;8:139-47.

44. Yuen MF, Seto WK, Fung J, Wong DK, Yuen JC, Lai CL. Three years of continuous entecavir therapy in treatment-naïve chronic hepatitis B patients: VIRAL suppression, viral resistance, and clinical safety. Am J Gastroenterol 2011;106:1264-71.

45. Liaw YF. Clinical utility of hepatitis B surface antigen quantitation in patients with chronic hepatitis $\mathrm{B}$ : a review. Hepatology 2011;53:2121-9.

46. Huo TI, Wu JC, Lee PC, et al. Sero-clearance of hepatitis B surface antigen in chronic carriers does not necessarily imply a good prognosis. Hepatology 1998;28:231-6.

47. Wong PY, Xia V, Imagawa DK, Hoefs J, Hu KQ. Clinical presentation of hepatocellular carcinoma (HCC) in Asian-Americans versus non-AsianAmericans. J Immigr Minor Health 2011;13: 842-8. 
48. Tseng TC, Liu CJ, Yang HC, et al. High levels of hepatitis B surface antigen increase risk of hepatocellular carcinoma in patients with low HBV load. Gastroenterology 2012;142:1140-9.

49. Tenney DJ, Rose RE, Baldick CJ, et al. Long-term monitoring shows hepatitis $\mathrm{B}$ virus resistance to entecavir in nucleoside-naive patients is rare through 5 years of therapy. Hepatology 2009;49: 1503-14.

50. Heo J, Ahn SH, Kweon YO, et al. Entecavir + adefovir versus lamivudine + adefovir or entecavir alone in lamivudine-resistant chronic hepatitis B: 96-week data from the DEFINE study. J Clin Exp Hepatol 2013;3(Suppl):S60.

51. Jablkowski M, Diculescu M, Janssen HLA, et al. The safety and efficacy of entecavir and tenofovir combination therapy for chronic hepatitis B in patients with previous nucleos(t)ide treatment failure. Hepatology 2013;58:711A (abstract 1044).

52. Zoutendijk R, Reijnders JG, Brown A, et al. Entecavir treatment for chronic hepatitis $\mathrm{B}$ : adaptation is not needed for the majority of naive patients with a partial virological response. Hepatology 2011;54: 443-51.

53. Luo J, Li X, Wu Y, et al. Efficacy of entecavir treatment for up to 5 years in nucleos(t)ide-naive chronic hepatitis B patients in real life. Int J Med Sci 2013;10:427-33.

54. Ko SY, Choe WH, Kwon SY, et al. Long-term impact of entecavir monotherapy in chronic hepatitis $B$ patients with a partial virologic response to entecavir therapy. Scand J Gastroenterol 2012;47: 1362-7.

55. Zoulim F. Mechanism of viral persistence and resistance to nucleoside and nucleotide analogs in chronic hepatitis B virus infection. Antiviral Res 2004;64:1-15.

56. Shouval D, Lai CL, Chang TT, et al. Relapse of hepatitis B in HBeAg-negative chronic hepatitis B patients who discontinued successful entecavir treatment: the case for continuous antiviral therapy. J Hepatol 2009;50:289-95.

57. Reijnders JG, Perquin MJ, Zhang N, Hansen BE, Janssen HL. Nucleos(t)ide analogues only induce temporary hepatitis $\mathrm{B}$ e antigen seroconversion in most patients with chronic hepatitis B. Gastroenterology 2010; 139:491-8.

58. Petersen J, Buggisch P, Stoehr A, et al. Stopping longterm nucleos(t)ide analogue therapy before HBsAg loss or seroconversion in $\mathrm{HBeAg}$ negative $\mathrm{CHB}$ patients: experience from five referral centers in Germany. Hepatology 2011;54:1033A (abstract 1417).

59. Hadziyannis SJ, Sevastianos V, Rapti I, Vassilopoulos D, Hadziyannis E. Sustained responses and loss of HBsAg in HBeAg-negative patients with chronic hepatitis B who stop long-term treatment with adefovir. Gastroenterology 2012;143: 629-36.
60. Song MJ, Song do S, Kim HY, et al. Durability of viral response after off-treatment in $\mathrm{HBeAg}$ positive chronic hepatitis B. World J Gastroenterol 2012;18: 6277-83.

61. Petersen J, Buggisch P, Hinrichsen H, et al. Stopping long-term nucleos(t)ide analogue therapy before HbsAg loss in HbeAg negative CHB patients: follow-up of long-term responders. J Hepatol 2013; 58:S313 (abstract 770).

62. Dusheiko G. Treatment of $\mathrm{HBeAg}$ positive chronic hepatitis B: interferon or nucleoside analogues. Liver Int 2013;33(Suppl 1):137-50.

63. Chan HL, Wong GL, Choi PC, et al. Alanine aminotransferase-based algorithms of liver stiffness measurement by transient elastography (Fibroscan) for liver fibrosis in chronic hepatitis B. J Viral Hepat 2009;16:36-44.

64. Wong GL, Wong VW, Choi PC, et al. Assessment of fibrosis by transient elastography compared with liver biopsy and morphometry in chronic liver diseases. Clin Gastroenterol Hepatol 2008;6:1027-35.

65. Fattovich G, Bortolotti F, Donato F. Natural history of chronic hepatitis B: special emphasis on disease progression and prognostic factors. J Hepatol 2008; 48:335-52.

66. Papatheodoridis GV, Chan HL, Hansen BE, Janssen HL, Lampertico P. Risk of hepatocellular carcinoma in chronic hepatitis B: assessment and modification with current antiviral therapy. J Hepatol 2015;62: 956-67.

67. Bruix J, Sherman M. Management of hepatocellular carcinoma: an update. Hepatology 2011;53:1020-2.

68. Wong VW, Chan SL, Mo F, et al. Clinical scoring system to predict hepatocellular carcinoma in chronic hepatitis B carriers. J Clin Oncol 2010;28: 1660-5.

69. Yuen MF, Tanaka Y, Fong DY, et al. Independent risk factors and predictive score for the development of hepatocellular carcinoma in chronic hepatitis B. J Hepatol 2009;50:80-8.

70. Yang HI, Yuen MF, Chan HL, et al. Risk estimation for hepatocellular carcinoma in chronic hepatitis $\mathrm{B}$ (REACH-B): development and validation of a predictive score. Lancet Oncol 2011;12:568-74.

71. Papatheodoridis G, Dalekos G, Sypsa V, et al. PAGE-B: risk score for hepatocellular carcinoma (HCC) development in Caucasian chronic hepatitis $\mathrm{B}(\mathrm{CHB})$ patients receiving entecavir (ETV) or tenofovir (TDF). J Hepatol 2014;60:S435 (abstract P1075).

72. Block TM, Gish R, Guo H, et al. Chronic hepatitis B: what should be the goal for new therapies? Antiviral Res 2013;98:27-34.

73. Matsuzaki T, Ichikawa T, Otani M, et al. The significance of hepatitis $B$ virus core-related antigen and covalently closed circular DNA levels as markers of $\mathrm{HBV}$ re-infection after liver transplantation. J Gastroenterol Hepatol 2013;28:1217-22. 
74. Wong DK, Seto WK, Fung J, et al. Reduction of hepatitis B surface antigen and covalently closed circular DNA by nucleos(t)ide analogues of different potency. Clin Gastroenterol Hepatol 2013;11: 1004-10.

75. Werle-Lapostolle B, Bowden S, Locarnini S, et al. Persistence of cccDNA during the natural history of chronic hepatitis B and decline during adefovir dipivoxil therapy. Gastroenterology 2004;126:1750-8.

76. Bowden S, Locarnini S, Chang TT, et al. Impact of entecavir versus lamivudine on hepatic HBV covalently closed-circular DNA and total hepatic HBV DNA in nucleoside-naïve $\mathrm{HBeAg}$ positive chronic hepatitis $\mathrm{B}$ patients. J Hepatol 2013;58:S308 (abstract 759).

77. Takkenberg B, Terpstra V, Zaaijer H, et al. Intrahepatic response markers in chronic hepatitis $\mathrm{B}$ patients treated with peginterferon alpha-2a and adefovir. J Gastroenterol Hepatol 2011;26:1527-35.

78. Cai D, Mills C, Yu W, et al. Identification of disubstituted sulfonamide compounds as specific inhibitors of hepatitis B virus covalently closed circular DNA formation. Antimicrob Agents Chemother 2012;56:4277-88.
79. Chan HL, Thompson A, Martinot-Peignoux M, et al. Hepatitis B surface antigen quantification: why and how to use it in 2011-a core group report. J Hepatol 2011;55:1121-31.

80. Lok AS, Trinh H, Carosi G, et al. Efficacy of entecavir with or without tenofovir disoproxil fumarate for nucleos $(\mathrm{t})$ ide-naive patients with chronic hepatitis B. Gastroenterology 2012;143:619-28.

81. Sonneveld MJ, van Vuuren AJ, Verhey E, et al. Adding peginterferon alfa-2a to entecavir increases $\mathrm{HBsAg}$ decline and $\mathrm{HBeAg}$ clearance: first results from a global randomized trial (ARES study). Hepatology 2012; 56(Suppl S1):199A (abstract 19).

82. Ning Q, Han M, Sun Y, et al. New treatment strategy: switching from long-term entecavir to peginterferon alfa-2a induces $\mathrm{HBeAg}$ seroconversion/HBsAg clearance in patients with $\mathrm{HBeAg}$ positive chronic hepatitis B. Hepatology 2012; 56(Suppl S1):300A (abstract 216).

83. Michel ML, Mancini-Bourgine M. Therapeutic vaccination against chronic hepatitis $\mathrm{B}$ virus infection. J Clin Virol 2005;34(Suppl 1):S108-14. 